\title{
Limited Focus on the Use of Health Care by Elderly Migrants-A Literature Review
}

\author{
Katarina Hjelm ${ }^{1}$, Björn Albin ${ }^{2 \dagger}$ \\ ${ }^{1}$ Department of Social and Welfare Studies, Linköping University, Norrköping, Sweden \\ ${ }^{2}$ School of Health and Caring Sciences, Linnaeus University, Växjö, Sweden \\ Email: "katarina.hjelm@liu.se
}

Received 4 April 2014; revised 6 May 2014; accepted 22 May 2014

Copyright (C) 2014 by authors and Scientific Research Publishing Inc.

This work is licensed under the Creative Commons Attribution International License (CC BY). http://creativecommons.org/licenses/by/4.0/

(c) (i) Open Access

\begin{abstract}
Our premise for this literature review is the global demographic change caused by the world's population living longer and becoming older, and extensive international migration leading to multicultural societies. Increasing age leads to health problems, often long-term or chronic, requiring investments in health care. Worse health and dissimilarities in pattern of morbidity/ mortality have been found in foreign-compared to Swedish-born persons, so it is reasonable to assume that this affects use of health care. The exploratory review focuses on elderly migrants' (>65 years) use of healthcare. The databases Pub Med, EBSCO, CINAHL and ERIC were searched in 2000-2013. A limited number of studies were found; few had a comparative approach, most were from the USA, and focused on migrants from the former Soviet Union or countries in South-East Asia. A range of factors were identified that influence patterns of health care use: language fluency, ability to communicate, self-reported health status, prevalence of chronic disease, physical distance from care provision, availability of transport to reach care, cost of care, the health insurance system, cultural norms and values regarding different forms of care, level of education, and length of residence in the host country. Most studies treated health care from a general perspective and collected data from community and hospital settings, without analysing usage separately. Some studies indicated elderly migrants making use of health care less than other groups but the pattern is not unambiguous: other studies show that there is an overuse of health care. It is therefore difficult to show any particular pattern, or possible differences in use, regarding community versus in-patient care. Studies focusing on migrants' actual use of health care are few and further research is needed, especially because elderly people form the largest group of users of health care and will be even larger in the future.
\end{abstract}

\section{Keywords}

Ageing, Elderly, Migrants, Consumption, Utilisation, Health Care, Health Resources

\footnotetext{
*Corresponding author.

${ }^{\dagger}$ The author is deceased.
} 


\section{Introduction}

The Swedish population today is of very heterogeneous origin, with more than 120 different nationalities represented [1]. Since the end of the Second World War the number of foreign-born persons has increased over time and today they constitute about $15 \%$ of the total population.

This review focuses on elderly immigrants' use of healthcare. In this section, we intend to address the question itself and also-perhaps more importantly-to outline the level of our research-based knowledge. This study should therefore be seen primarily as an exploratory outline of the research on this subject. We pose the questions: What are the main trends? What themes are in focus? What are the main leads?

Our starting point for this review is the global demographic change caused by the world's population living ever longer and becoming ever older [1] [2], as well as extensive international migration that leads to multicultural communities [3]. With increasing age come different health problems, often of a long-term or chronic nature, which, in their turn, demand different investments in care [4]. In studies of foreign-born people living in Sweden, it has been found that, measured objectively, they have worse health than those born in Sweden, for example in deaths from heart and circulatory disease, cancer and at an earlier age [5] [6]. The patterns of morbidity and mortality of Swedish people, compared with foreign-born individuals living in Sweden, are different [5]-[8]. Thus, it is reasonable to assume that this affects the use of health care. It is now time to assemble the available knowledge on elderly people's use of health care since; in future, they are going to form an increasing proportion of the population. Such knowledge can form an important foundation for the future planning of different care provisions, not least in the attempt to achieve the Swedish health care objective of delivering the same standard of care to the whole population, irrespective of background [9].

In the following the terms of immigrant, foreign-born and migrant will be used interchangeably with regard to people born in a country other than the one studied. By "elderly" we mean people over 65 years of age, which is the usual Swedish definition and the commonest age for retirement. This involves a wide range in age and in individual needs and wishes, not least in the use of health care. This span is further emphasised by the fact that the care and service that are delivered and offered by the municipalities differs in both quantity and quality [10] [11].

\subsection{Health and Living Conditions of Migrants}

Let us begin with the nature of the problem itself, viewed from the aspects of health, organisation and utilisation. Within the heterogeneous migrant population in Sweden, the majority live in socially and economically vulnerable conditions, as in many other countries particularly in Europe. Many are dependent on benefits, they have greater difficulties in supporting themselves, a weaker position in the labour market, a higher proportion of unemployed and they are at greater risk of early retirement than the native population [12]-[15]. Many also have worse conditions in their living and working environments, often living in areas where the host population does not wish to live [15]. These circumstances are particularly noticeable in groups of non-Europeans who have arrived since the 1980s. Later data certainly show that the employment situation for foreign-born people has improved but the contrast with the Swedish population is great [16]. There is even a considerable difference between those born in Sweden of immigrant parents and those with Swedish parents [16].

Since living and socio-economic conditions influence a person's health, we can expect to find differences between the health of migrants and that of native-born. Today's research into migrants' morbidity and mortality patterns indicates poorer health, both subjectively and objectively measured, and a somewhat different morbidity in immigrant groups, which also varies between groups [5] [6] [8] [17]-[19].

The above changes in Sweden, with an increased number of elderly people, among whom there are many foreign-born people with a rather different pattern of morbidity and mortality, are going to influence various sectors in the country, for example, the health care system.

\subsection{The Health of Elderly Immigrants}

Just as the proportion of those termed elderly (aged 65 and over) has increased in Sweden, so has the proportion of elderly immigrants. A demographic report from the National Board of Health and Welfare estimated that older immigrants would make up 10\% of those over 65s by 2009 [20]. Health and functional ability are fundamental when it comes to the planning and organisation of care for older people. They determine what are their 
true requirements of care [4]. Previous positive images of progress in health in old age are no longer so unequivocal and there are differences in access to care and services, based on gender, ethnicity and relatives' willingness and ability to help. With increasing age comes a mounting need for the care that is provided mainly by the professional care sector, though relatives' involvement in care has also increased. Care needs are determined by both objective and subjective factors, for example perceived health status, social networks and living conditions [21] [22]. It is therefore important to remember that there are considerable differences between the various groups of immigrants. What is lacking are longitudinal studies with national and representative samples. One difficulty lies in demographic studies that separate out immigrant groups so that the sample size is restricted. The body of evidence points to differences in quality of life between native- and foreign-born people. The low socio-economic status of many immigrants in Sweden is especially significant [15]. Living conditions vary; above all, people from the Middle East, North Africa and southern Europe have lived under the most restricted economic conditions. The lengthy of time spent in Sweden also plays a part. Someone who has been resident in Sweden for twenty years or more often has a similar economic situation to a native Swede [16]. Foreign-born people, in general, maintain a smaller economic margin in comparison with those born in Sweden, and these differences increase considerably among older pensioners [15] and for some age groups of elderly people depending on the construction of the Swedish pension system [23].

\subsection{The Organization of Health Care for Elderly Immigrants}

The development of a health care system that responds to a changed demographic structure and population composition, as far as cultural background is concerned, is a challenge for health care systems in Europe [3]. It can be seen as a necessary development task [24]. Qualitative improvement can be described by six important objectives: safety, efficiency, patient focus, measures taken at the right time, appropriateness of measures and equality of care. This last is decisive: we achieve truly good-quality care only when it is accessible to all, native and immigrant, equivalent and equal in kind.

The Swedish Health and Medical Services Act $§ 2$ [9] states clearly that "the objective of the health care system is good health and care of the same standard for the whole population. Care is to be planned according to individual need and given with respect for everyone's equal worth and the dignity of the individual. Those who have the greatest need of health care are to be given priority."

\subsection{Use of Health Care and Social Service Provisions by Elderly Immigrants}

A Nordic review of care provision for elderly immigrants concludes that there is a lack of knowledge of how elderly immigrants make use of various care provisions in the different countries [25]. In several research contexts there are indications that elderly immigrants use formal old-age care to a lesser extent than do elderly Swedish people, despite changes in the range of services [26]-[32]. A study of people with known diabetes shows that the Swedish-born used more community nursing than did the foreign-born, even though their care needs were no greater [33]. Research and statistics also show that there are differences between different immigrant groups, which is the case in many countries. Fewer people from minority groups receive formal care, for example, in the USA. Hispanic and black people are under-represented as users of the equivalents to home help and sheltered housing [27].

It does not appear that elderly immigrants are included in Swedish old age care to any great extent. The explanation is often sought in questions of culture, linguistic competence, reception of care and the immigrant's difficulties in navigating the Swedish system [26] [34]-[36]. It has also been suggested that immigrant groups have a sceptical view of the nature of Swedish old age care, connecting this view to traditional forms of care and attitudes to it, which implies that they prefer care by relatives at home [37]. The question is therefore whether scepticism about other forms of care also applies to the use of health care by elderly immigrants in Sweden, which is what our study aims to investigate. To put our study in context, we present an overview of the international research on the use of health care by elderly immigrants.

\section{Method of Studying the State of Knowledge}

The overview takes as its starting point a literature search in the databases PubMed, EBSCO, CINAHL and ERIC in December 2013, using the key words: migrants, immigrants, consumption, utilisation, health care, 
health resources and combinations of these. The search was restricted to the time period from 2000 onwards and to literature in English and where it was stated that elderly persons, i.e. over 65 years of age, had been studied or where the terms elderly, ageing or elderly persons were used in the description of the study population. References in recently published studies were also scrutinised, government reports were searched, and discussions were held with researchers regarding key references. The knowledge base relevant to use of health care [38] was reviewed by systematic methods [39].

\section{The State of Knowledge}

In the literature search, we found that the study population in many of the studies were not migrants but various minority groups (minority/racial/ethnic groups). This was the case especially in research carried out in the United States. These investigations were therefore excluded, since they did not deal with migrants or discuss the context of migrational background. Most of the studies were not limited to elderly persons (65 years or above) but dealt more generally with the whole (study) group's use of health care, usually groups with children or mixed-age adults.

When these studies had been weeded out, there remained nine that applied to elderly people's health care consumption [40]-[48]. Most also dealt with the use of "social services" [40] [41] [43]-[45]. The concept of "social services" corresponds to the Swedish terms "omsorg" and "omsorgsinsatser". Most were conducted in the USA [41] [42] [44] [46] [47], one in Israel [45], another in the Netherlands [48], and two in Sweden [40] [43].

The majority of the studies employed a quantitative methodology [40] [42] [45]-[48]. Only three of the studies used a comparative approach and attempted a comparison between migrants and native-born people in the host country [40] [46] [47]. Most of the previous studies focused on certain migrant groups [41] [42] [44] [45] [47] and not on foreign-born persons in general [40] [46]. Those who have migrated from the former Soviet Union or from countries in South-East Asia have been studied more thoroughly [41] [42] [44] [45] [47].

A common difficulty in reviewing earlier investigations is that the concept of elderly is defined differently in different studies. The usual threshold for signifying old age is 65 years but some studies place it at 55 or 67 years [41] [45] [48]. This is a sign that the beginning of old age and what it implies is regarded differently in different cultures and contexts, and thus the concept of ageing is fairly relative [49].

\subsection{Patterns of Health Care Utilization}

The above studies indicate that elderly immigrants make use of health care less than other groups [40]-[48]. The pattern, though, is not unambiguous: studies of migrants from the former Soviet Union show, on the contrary, that there is an overuse of health care [41] [45] [47]. One factor that is thought to influence the use of health care is the length of time spent in the new country, which, in turn, affects one's access to the resources that facilitate the use of health services [45] [46]. Level of education also plays its part [42] [44] [48] as well as language competence, being part of acculturation [48]. A comparative study investigating native Dutch people with the main four migrant groups in the Netherlands originating from Turkey, Surinam, Morocco and the Netherlands Antilles showed a higher use of GP services and a lower use of home care and physical therapy in immigrant elderly persons, but this was related to poorer self-reported health and higher prevalence of chronic diseases [48]. Utilisation of care is also influenced by a health care system based on private insurance, which is the case in the USA. If private insurance is lacking, or inadequate, one cannot pay for the care that is needed, which means that the overall use of care is reduced. Those studies that find under use of care also suggest that elderly immigrants have a greater need of health care input. Their ability to gain access and to use it is restricted, partly as a result of the economic reasons already mentioned [44] [45] [48].

\subsection{Barriers to Access to Health Care Services}

The studies listed describe a series of different barriers that can impede access to health care and therefore lead to under use of services. Inability to speak the language and to communicate with others is one of the principle barriers [48]. Translation may be needed, sometimes even within one immigrant group, e.g. the Chinese [44].

Another barrier may be the distance to the health centre or hospital [44] [45]. Transport is an important requirement for access to care facilities.

As already mentioned, various migrant groups are living in socially and economically deprived circumstances, 
hence the cost of health services can be an obstacle [42] [44] [46]. Several studies show that where people are excluded from some form of health insurance, the utilisation of care is reduced even if the need for care is great. The cost may also be related to waiting lists and waiting time in order to get access to health care [44].

Cultural norms and values in certain groups are shown to be significant in the use of health care [41] [46]. Studies of Chinese immigrants, for example, have found a suspicion of Western medicine, with the implication that self-care or consultation within the ethnic group is preferred to a Western form of care. Several of the immigrant groups that have been researched see it as the family's role to take in hand and care for their sick members. This influences the pattern of seeking care: one turns first towards and expects help from the family, the informal sector, and not from the professional care providers in the various institutions [41] [46] [48].

Hence, cultural norms and values come to determine how a country's health care system develops and create the conditions in which an individual seeks care [44]. Different countries therefore have different health care systems so that an immigrant, especially one who is newly-arrived, may have difficulty understanding and using the system. Information about the health care system can remove the obstacles to seeking care and facilitate care at the appropriate level within it. The educational level and knowledge of the system in the previous homeland need to be considered [47]. A higher level of education reduces the use of health care and makes it more effective, since people deal better with information on the structure and use of their health service. The geographical separation and dispersal of immigrants within a country influences the use of health care [44]. Concentrations of large migrant groups, for example, mean that they can better state their wishes with regard to the state's investment in care and also that they are more likely to make their voices heard in their new environment.

\section{Discussion}

A limited number of studies have been revealed in the literature review focusing on elderly migrants' use of health care and social service. However, in those found a range of factors have been identified that influence patterns of health care use in elderly migrants, as follows: language fluency and ability to communicate, self-reported health status and prevalence of chronic disease, physical distance from care provision, availability of transport to reach the care, cost of care, the health insurance system, cultural norms and values regarding different forms of care, cost of care, level of education, and length of residence in the host country. It is therefore difficult to show any particular pattern, or possible differences in use, regarding community versus in-patient care. The majority of the studies treated health care from a general perspective and collected data from both community and hospital settings, without analysing usage separately. However, there is a Swedish study [33] that shows that foreign-born diabetics, mainly Scandinavian labour migrants with a short cultural distance (similarities in language, social structure, religion, living standards and cultural norms and values) and a long residence in Sweden, used community/home care less than did Swedish-born people. This was in spite of having a greater need of care, as measured by the KATZ ADL index. It is therefore worth noting that there were otherwise no differences in the utilization of care and the same results were shown in an earlier Swedish investigation [50]. A Dutch study investigating the main immigrant groups in the country likewise showed underutilisation of all kinds of care except GP services, which was related to self-reported health and chronic disease [48].

Some studies describe the use of informal care reported by relatives, family and elderly people within the same ethnic group, as well as self-care [44]. Migrants of Asian origin preferred to turn to the informal sector, and use of the various care institutions was reported by professional care givers as lower and largely determined by a person's financial situation. The better the financial resources, the higher the use of self-care and use of health care services, meaning that people who used self-care to a high degree also used various health services to a high degree [47].

In this study of migrants' use of health care, there are some problems of definition, as the boundary between "social care" and health care is not always quite clear. Some researchers [45] [51] use the term "health social work", which has no clear Swedish translation but can be taken to mean a social worker's involvement in various health care arrangements. In cases where it is used, studies of Russian migrants, for example, show that recent immigrants use such a service less than those with a long period of residence in the host country [45]. The same is true of comparisons between migrants and the native population in Israel [51].

\section{Conclusions}

In conclusion, studies focusing on migrants' actual use of health care are few and it is therefore a topic that 
needs further research. There remain a number of questions, such as: What sort of care is used and does the level of care differ from that of Swedes? Are there differences in the use of diverse forms of care between the various groups of immigrants? If there are differences, what is the reason for them? To what degree is private care used, as opposed to public care? Do people prefer care by the family at home to provision by official organisations, such as the municipality and the county?

It is worth noting that recent reports from the National Board of Health and Welfare on public health and social conditions [16] [19] and the care of elderly people [52] refer to general development patterns for the health of the Swedish people and the development of care for the aged as a whole group. There is no specific information on people with a foreign background. However, it is stated that there are differences in access to care based on ethnicity.

Even if the studies we have used here provide a certain pointer to the use of health care, it is important in the analysis of results to remember that there are major differences in the structure and financing of health services in different countries. Similarly, the living conditions of the various immigrant groups differ from one country to another. The results are therefore not directly transferable to the Swedish situation.

There could be several reasons for the lack of research on this topic. One contributory factor might be obtaining access to official/national data on the use of health care, especially community care. The data currently collected tend to deal with the quality of various activities and not patterns of care use [52]. Another important reason could be that interest in the health of migrants has only recently surfaced, with research into other age groups taking priority, e.g. children and young people and people of working age.

Migrants' difficulties within the health care system have been noticed within the European Union, which has funded a major project, "Migrant-friendly Hospitals". The project, which involved twelve participant countries and ran from 2002-2004, focused on three areas: improving interpretation services, information and education for migrants within mother and child health care and the education of culturally competent personnel [53]. The result of the project was the "Amsterdam Declaration", which made 21 recommendations for adapting and developing health services for the benefit of migrants [54]. The Declaration states that migrants' representatives may act as a mouthpiece for articulating their group's needs, that care personnel should be developed in crosscultural competence and that care should become individualised and person-centred. Even though the project does not focus explicitly on elderly immigrants as a group, it does provide a framework for developing measures for this group in particular. This is necessary, not least because elderly people form the largest group of users of health care and it will be even larger in the future. An ageing population carries an increasing proportion of people with chronic health problems, which gradually leads to a mounting need for care and service provisions from the state, the cost of which will stretch the health service's already limited resources. Within such economic limitations, there needs to be a gathering of strength in the development and organisation of care. The aim should be to bring together sound knowledge of all groups in the community and what their needs are.

\section{Acknowledgements}

This work was supported by grants from the research profile AMER (Arbetsmarknad, Migration och Etniska Relationer (Labour Market, Migration and Ethnic Relations)), Växjö University, and support for the research environment Samhälle, Hälsa och Vård (SHV) (Society, Health and Care), Linnaeus University, Växjö, Sweden.

\section{Author Contributions}

Hjelm K.: Conception and design of study, data collection, data analysis and interpretation of results; drafting and preparation of the manuscript for publication.

Albin B.: Conception and design of study, data collection, data analysis and interpretation of results; drafting and preparation of the manuscript for publication.

\section{Conflict of Interest}

The authors declare that they have no competing interests.

\section{References}

[1] Sveriges Officiella Statistik (SOS) Befolkningsstatistik 20131231 (Official Statistics of Sweden. Population statistics). 
[2] Victor, C. (2005) The Social Context of Ageing. Routledge, London. http://dx.doi.org/10.4324/9780203338599

[3] International Organisation of Migration (IOM) (2008) World Migration 2008. Managing Labour Mobility in the Evolving Global Economy. http://www.iom.int/jahia/Jahia/cache/offonce/pid/1674?entryId=20275

[4] Socialstyrelsen (2010) Lägesrapport 2010; Folkhälsa, Hälso-ochsjukvård, Individ och familjeomsorg, Stöd och service till personer med funktionsnedsättning, Vård och omsorg om äldre. (State of the art 2010, Public Health, Health care, Care of individuals and families, Support and service to persons with disabilities, Care and social service for elderly persons). http://www.socialstyrelsen.se/publikationer2010/2010-3-14/Documents/2010-3-21\%20Lägesrapport\%202010.pdf

[5] Albin, B., Hjelm, K., Ekberg, J. and Elmståhl, S. (2005). Mortality among 742668 Foreign- and Native-Born Swedes 1970-1999. European Journal of Public Health, 5, 511-517. http://dx.doi.org/10.1093/eurpub/cki026

[6] Albin, B., Hjelm, K., Ekberg, J. and Elmståhl, S. (2006). Higher Mortality and Different Pattern of Causes of Death among Foreign-Born Compared to Native Swedes 1970-1999. Journal of Immigrant and Minority Health, 2, 101-113. http://dx.doi.org/10.1007/s10903-006-8519-z

[7] Albin, B., Hjelm, K. and Elmståhl, S. (2010) Lower Prevalence of Hip Fractures in Foreign-Born Individuals than in Swedish-Born individuals During the Period 1987-1999. BMC Musculoskelet Disord, 11, 203. http://dx.doi.org/10.1186/1471-2474-11-203

[8] Albin, B., Hjelm, K. and Elmståhl, S. (2013) Comparison of Stroke Mortality in Finnish-Born Migrants Living in Sweden 1970-1999 and in Swedish-Born Individuals. Journal of Immigrant and Minority Health, 16, 18-23.

[9] SFS (1982:763) Hälsooch sjukvårdslag (The Swedish Health and Medical Services Act).

[10] Trydegård, G-B. (2000) Tradition, Change and Variation. Past and Present Trends in Public Old-Age Care. Stockholm Studies of Social Work 16. Department for Social work, Stockholm University.

[11] Nordell, E. and Elmståhl, S. (2010) Kommunal äldreomsorg i Skåne. Enkätundersökning om boende, resurser och insatser (Municipal LTC in Skåne. Survey on housing, resources and provision of services). Media Tryck, Lund University, 1-20.

[12] Ekberg, J. (1994) Är invandrarna fattiga? (Are Immigrants Poor?) Ekonomisk debatt, 22, 169-177.

[13] Ekberg, J. and Andersson, L. (1995). Invandring, sysselsättning och ekonomiska effekter (Immigration, employment and economic effects). Finansdepartementet Ds 1995:68, Stockholm.

[14] Ekberg, J. and Rooth, D-O. (2000) Arbetsmarknadspolitik för invandrare. (Labour Market Politics for Immigrants). Växjö University Working Paper Series no 6.

[15] Socialstyrelsen (2006) Social Rapport (Social Report). Norstedts Tryckeri, Stockholm.

[16] Socialstyrelsen (2007) Folkhälsa och sociala förhållanden. Lägesrapport 2007 (Public Health and Social Circumstances).

http://www.socialstyrelsen.se/NR/rdonlyres/67B2B9CD-2D4F-4729-A57C-D6448CA26E57/10262/20081318_rev1.pd $\underline{\mathrm{f}}$

[17] Socialstyrelsen (1995) Invandrares hälsa och sociala förhållanden (Immigrants’ Health and Social Circumstances). Epidemiologiskt centrum, Stockholm.

[18] Leao, T., Sundquist, J., Johansson, S.E. and Sundqvist, K. (2009) The Influence of Age at Migration and Length of Residence on Self-Rated Health among Swedish Immigrants: A Cross-Sectional Study. Ethnicity \& Health, 14, 93-105. http://dx.doi.org/10.1080/13557850802345973

[19] Socialstyrelsen (2009) Folkhälsorapport 2009 (Public Health Report 2009). http://www.socialstyrelsen.se/Publicerat/2009/10363/2009-126-71.htm

[20] Socialstyrelsen (1999) Äldre födda utomlands-en demografisk beskrivning (Elderly Persons Born Abroad—A Demographic Description). Socialstyrelsen, Stockholm.

[21] Bränd Persson, K., Slaug, B., Nyberg, P., Korpela, M., Isacsson, Å. and Borgquist, L. (1997) Vårdkonsumtion under en 20-årsperiod i Dalby och Tierp. Studentlitteratur, Lund.

[22] Hjelm, K. (1998) Migration, Health and Diabetes Mellitus-Studies Comparing Foreign- and Swedish-Born Diabetic Subjects Living in Sweden. Ph.D. Dissertation. Studentlitteratur, Lund.

[23] Ekberg, J. and Lindh, T. (2011) Pensionsreformen och invandrarna (The Retirement Reform and the Immigrants). Ekonomisk Debatt, 39, 33-40.

[24] Bischoff, A. (2003) Caring for Migrant and Minority Patients in European Hospitals. Swiss Forum for Migration and Population Studies, Neuchatel and Basel.

[25] Ingebretsen, R. and Nergård, T.B. (2007) Eldre med invandrebakgrunn (Elderly Persons with Immigrant Background). Norsk Institutt for forskning om oppvekst, velferd og aldring, Rapport 13/07, Oslo. 
[26] Eriksson, T. (1996) Hur möter äldreomsorgen invandrare? (How Does Elderly Care Encounter Immigrants?) Socialmedicinsk tidskrift nr 7-8.

[27] SOU (1997:76) Invandrare i vård och omsorg-en fråga om bemötande av äldre (Immigrants in Health Care and Elder Care-A Matter of Attitude to Elderly Persons). Fritzes, Stockholm.

[28] Gaunt, D. (2002) Äldre invandrare (Elderly Immigrants). In: Magnússon, F., Ed., Etniska relationer $i$ vård och omsorg (Ethnic Relations in Health Care and Social Service), Studentlitteratur, Lund.

[29] Socialstyrelsen (2002) Äldre utanför äldreomsorgen (Elderly Persons Outside Elderly Care). http://www.sos.se/fulltext/123/2002-123-63/2002-123-63.pdf

[30] Forssell, E. (2004) Skyddandets förnuft. En studie om anhöriga till hjälpbehövande äldre som invandrat sent i livet. Stockholms universitet. Institutionen för socialt arbete, Socialhögskolan, Stockholm.

[31] Pudaric, S., Sundquist, J. and Johansson, S.E. (2003) Country of Birth, Instrumental Activities of Daily Living, Self-Rated Health and Mortality: A Swedish Population-Based Survey of People Aged 55-74. Social Science \& Medicine, 56, 2493-2503. http://dx.doi.org/10.1016/S0277-9536(02)00284-8

[32] Hovde, B., Edberg, A.K. and Hallberg, I. (2008) Public Care among Older Non-Nordic Immigrants in Sweden in Comparison with Nordic Born Controls. Vård I Norden, 28, 9-13.

[33] Hjelm, K., Apelqvist, J., Nyberg, P., Sundquist, J. and Isacsson, Å. (1997) Health, Health Care Utilisation and Living Conditions in Foreign-Born Diabetic Patients in Southern Sweden. Journal of Internal Medicine, 242, 131-141. http://dx.doi.org/10.1046/j.1365-2796.1997.00161.x

[34] Ekman, S.L. and Emami, A. (1998) Living in a Foreign Country in Old Age-Life in Sweden as Experienced by Elderly Iranian Immigrants. Health Care in Later Life: An International Research Journal, 3, 183-198.

[35] Emami, A., Torres, S., Lipson, J.G. and Ekman, S.L. (2000) An Ethnographic Study of a Day-Care Center for Iranian Immigrant Seniors. Western Journal of Nursing Research, 22, 169-188. http://dx.doi.org/10.1177/019394590002200205

[36] Heikkilä, K. (2004) The Role of Ethnicity in Care of Elderly Finnish Immigrants. Ph.D. Dissertation, Department of Neurotec, Centre of Excellence in Elderly Care Research, Karolinska Institutet, Stockholm.

[37] Socialstyrelsen (2000) Anhöriga till äldre invandrare. En fallstudie av anhöriga till äldre utomeuropeiska invandrare utan offentlig äldreomsorg (Relatives of Elderly Migrants. A Case Study of Relatives of Non-European Immigrants Outside Public Elderly Care). Rapport Anhörig 300, 2000:4, Stockholm.

[38] Cooper, H.M. (1998) Synthesizing Research. A Guide for Literature Reviews. Sage Publications, Thousand Oaks, California.

[39] Joanna Briggs Institute (JBI) Joanna Briggs Institute Reviewers’ Manual 2014. http://www.joannabriggs.org/assets/docs/sumari/ReviewersManual-2014.pdf

[40] Albertsson, M., Albin, B., Siwertsson, C. and Hjelm, K. (2004) Consuming Care and Social Services: Comparisons between Swedish-Born Older People and Older People Born Outside Sweden. Practice, 16, 99-110. http://dx.doi.org/10.1080/09503150412331313079

[41] Aroian, K., Wu, B., Khatutsky, G., Tran, T. and Balsam, A. (2001) Health and Social Service Utilization among Elderly Immigrants from the Former Soviet Union. Journal of Nursing Scholarship, 33, 265-271. http://dx.doi.org/10.1111/j.1547-5069.2001.00265.x

[42] Sohn, L. and Harada, N. (2004) Time since Immigration and Health Services Utilization of Korean-American Older Adults Living in Los Angeles County. Journal of the American Geriatrics Society, 52, 1946-1950. http://dx.doi.org/10.1111/j.1532-5415.2004.52524.x

[43] Albin, B., Albertsson, M., Ekberg, J. and Hjelm, K. (2005) Health and Consumption of Health Care and Social Service among Old Migrants in Sweden. Primary Health Care Research and Development, 6, 37-45. http://dx.doi.org/10.1191/1463423605pc212oa

[44] Aroian, K., Wu, B. and Tran, T. (2005) Health Care and Social Service Use among Chinese Immigrant Elders. Research in Nursing \& Health, 28, 95-105. http://dx.doi.org/10.1002/nur.20069

[45] Soskolne, V., Auslander, G. and Ben-Shahar, I. (2006) Help Seeking Barriers to Utilisation of Medical and Health Social Work Services among Ageing Immigrants to Israel from former Soviet Union. Health and Social Care in the Community, 14, 74-84. http://dx.doi.org/10.1111/j.1365-2524.2005.00601.x

[46] Choi, S. (2006) Insurance Status and Health Service Utilization among Newly-Arrived Older Immigrants. Journal of Immigrant and Minority Health, 2, 149-161. http://dx.doi.org/10.1007/s10903-006-8523-3

[47] Aroian, K., Jillon, S. and Vander, W. (2007) Health Service Use in Russian Immigrant and Nonimmigrant Older Persons. Family \& Community Health, 3, 213-223. http://dx.doi.org/10.1097/01.FCH.0000277764.77655.b7 
[48] Denktas, S., Koopmans, G., Birnie, E., Foets, M. and Bonsel, G. (2009) Ethnic Background and Differences in Health Care Use: A National Cross-Sectional Study of Native Dutch and Immigrant Elderly in the Netherlands. International Journal for Equity in Health, 8, 35. http://dx.doi.org/10.1186/1475-9276-8-35

[49] Magnússon, F. (2007) Åldrandets utanförskap (The Exclusion of Ageing). In: Zanderin, L. and Staaf, A., Eds., Mänskliga rättigheter i svensk belysning (Human Rights in Swedish Illumination), Liber, Lund.

[50] Waern, E. and Steen, B. (1995) Äldre invandrares hälsa jämförd med svenskars. Största skillnaderna av subjektiv karaktär (Elderly Immigrants Health Compared to Swedes. The Greatest Differences Related to Subjective Perceptions). Läkartidningen, 92, 515-518.

[51] Auslander, G., Soskolne, V. and Ben-Shahar, I. (2005) Utilization of Health Social Work Services by Older Immigrants and Veterans in Israel. Health \& Social Work, 30, 241-251. http://dx.doi.org/10.1093/hsw/30.3.241

[52] Socialstyrelsen (2007) Vård och omsorg om äldre. Lägesrapport 2007 (Care and Social Service for Elderly Persons. State of the Art 2007).

http://www.socialstyrelsen.se/Lists/artikelkatalog/Attachments/8863/2008-131-6_20081316.pdf

[53] European Union (2005) Project Summary. Migrant-Friendly Hospitals Project. http://www.mfh-eu.net/public/experiences_results_tools/review.htm

[54] Amsterdam-Declaration (2004) The Amsterdam Declaration towards Migrant-Friendly Hospitals in an Ethno-Culturally Diverse Europe. http://www.mfh-eu.net/public/european_recommendations.htm 